\title{
LA SENDA ESPINOSA DE LA VIDA DEL INTERBRIGADISTA RUDOLF BOLFÍK (1913-1941) ${ }^{1}$
}

por DAVID MAJTENYI

(Museo Nacional, Praga)

\author{
The Thorny Path of the Life of the International Brigades member Rudolf Bolfík \\ (1913-1941)
}

\begin{abstract}
The study is concerned with a biography of Rudolf Bolfík, former Czechoslovak air force engineer and gendarme cadet. Bolfík deserted from the gendarme school and attempted to leave for civil-war torn Spain. He succeeded at his third attempt and reached Spain in 1938, enlisting in the battalion Divisionario. After the breakdown of the Spanish front and a short term internation in France he enlisted with the Czechoslovak army in exile in France, was evacuated to Britain from collapsing France, and joined the RAF Squadron no. 311, as a gunner. Bolfík died on return from his fourth sortie when his bomber had an accident over the North Sea.
\end{abstract}

Keywords: Czechoslovakia; Spanish civil war 1936-1939; Royal Air Force

Rudolf Bolfík figura entre más de dos mil voluntarios procedentes de nuestro país que prestaron oídos al llamamiento de un país lejano detrás de los Pirineos. ${ }^{2}$ Su camino, que se describe en las siguientes líneas, no carecía de momentos dramáticos: a España logró llegar a finales de mayo de 1938, después de haberlo intentado tres veces. Junto con los demás, vivió la etapa final del sangriento drama de la guerra. La suerte no fue en su caso favorable: el tiempo le midió apenas sólo 27 años de vida. La interesante y penosa vida de Rudolf Bolfík, con todas las peripecias y revueltas, merece estar grabada en la memoria. ${ }^{3}$

1 Este trabajo surgió gracias al apoyo financiero del Ministerio de Cultura de la República Checa, dentro del marco del financiamiento institucional del desarrollo conceptual de largo plazo, de la organización investigativa del Museo Nacional (DKRVO 2019-2023/16.III.a, 00023272).

2 Entre los investigadores que se dedican a la problemática de los brigadistas y su destino a largo plazo pertenecen, por ejemplo, PhDr. Jaroslav Bouček, CSc. Entre los representantes de la generación más joven citemos al director actual de SOkA Vsetín PhDr. Tomáš Baletka, Ph.D. luego a Petr Lukeš, (LHS) o Mgr. Zdenko Maršálek, Ph.D., de ÚSD AS ČR.

3 Este estudio surge parcialmente de la versión checa del artículo, publicado hace poco en Moderni dějin (Historia Moderna). Véase David MAJTENYI, "Od interbrigadisty k palubnímu střelci 311. perutě RAF - rotný Rudolf Bolfík (1913-1941)” [El sargento mayor Rudolf Bolfík (1913-1941): del interbrigadista al tirador de a bordo de la $311^{a}$ Escuadra de Royal Air Force], Moderní dějiny 25/2, Praha 2017, pp. 105-122. Por primera vez me ocupé de la figura de Rudolf Bolfík en un contexto más amplio junto con el PhDr. Jiří Rajlich; se trata de una síntesis más extensa -dedicada a los pilotos checoslovacos que lucharon en la Guerra Civil de España, de 1936 a 1939- a la que me refiero en 
El pequeño pueblo Mikulčice, cerca de la ciudad de Hodonín en la Moravia del Sur, con su castillo que fue uno de los centros del Reino de Gran Moravia, es conocido a los interesados, ante todo, por los aficionados a este atractivo capítulo de nuestra historia. En la actualidad, lo conocen muy bien los amantes del buen vino, ya que su nombre resuena también en relación con la vinicultura que dio fama a toda la región. Y fue allí donde Rudolf Bolfík nació el 13 de marzo de 1913 como el hijo mayor de Jan Bolfík (* 29. 5. 1886 - † 13. 8. 1939) y de Helena Šteflovičová Bolfíková (* 15.6. 1884 - †29.1. 1961). Toda la familia, junto con el hijo menor Ladislav (*11.10.1919), vivieron en la casa No. 211 y profesaban la mayoritaria religión romano-católica. El pequeño Rudolf frecuentó cinco cursos de la escuela básica, después pasó tres años en la escuela primaria superior en Hodonín y otros tres más en la escuela complementaria, en la que aprendió el oficio de electrotécnico. ${ }^{4}$

Antes de alistarse al servicio militar obligatorio, Rudolf Bolfík pasó a ser estudiante de la Escuela especializada de Aviación, que formaba parte de la Academia Aviáción Militar (VLU) de Prostějov, al igual que muchos otros jóvenes a los que les encantaban los aviones. Desde el punto de vista de especialización, esta escuela preparaba a los futuros suboficiales de la Aviación checoslovaca. Rudolf Bolfík empezó a estudiar allí el 1 de octubre de 1931; sin embargo, no logró entrar en el curso para pilotos cuyo entrenamiento duraba dos años. Estudió en el grupo de especialistas de tierra, la duración de su formación fue un solo año. El futuro mecánico de aviación aprobó los exámenes teóricos el 16 de abril de 1932, con la clasificación "buena", ocupando el $25^{\circ}$ lugar entre 72 egresados de la escuela. El 14 de septiembre de 1932

algunos casos también en este estudio. Jiří RAJLICH - David MAJTENYI, Jan Ferák a ti druzí čs. interbrigadisté, letci a letouny v občanské válce ve Španělsku 1936-1939 [Jan Ferák y los demás: interbrigadistas checoslovacos, pilotos y aviones en la Guerra Civil de España 1936-1939], Cheb 2012, pp. 452-467.

$4 \quad$ El Archivo Histórico Militar de Bratislava (Vojenský historický archív Bratislava, en adelante sólo VHA), Bratislava, Colección de pliegos básicos militares - Rudolf Bolfík; Archivo Distrital Estatal de Hodonín (Státní okresní archiv Hodonín, en adelante sólo SOkA), Hodonín, Fondo de Actas y documentos del censo del año 1921 - Mikulčice, y la carta al autor, del 6 de febrero de 2008, No. SOkA-HO 58/2008; Archivo Central Militar - Archivo Histórico Militar (Vojenský ústřední archiv - Vojenský historický archiv Praha, en adelante sólo VÚA - VHA, Praha), Fondo de Ingerbrigadistas Checoslovacos (Českoslovenští interbrigadisté), Rudolf Bolfík; Archivo Nacional Praga (Národní archiv Praha, en adelante sólo NA, Praha), Fondo de la Unión de Combatientes Antifascistas, Comité Central, Praga (Svaz protifašistických bojovníků - ústřední výbor, Praha): cuestionario, hoja de inscripción - Bolfík Rudolf 1913; Archivo Provincial de Moravia - archivo de Brno (Moravský zemský archiv - Brno, en adelante sólo MZA), Brno, Fondo de la Comandancia Provincial de Gendarmería, Brno (Zemské četnické velitelství), Brno B 72, cartón 169, sign. 7860: Memoria de la Jefatura del Cuartel de České Budějovice, a propósito del detenimiento de Rudolf Bolfík, fechada el 31 de diciembre de 1937; Jaroslav HOŠEK, Čs. interbrigadisté [Interbrigadistas checoslovacos] - No. 148, Rudolf Bolfik, Praha 1975; František LOUCKÝ, Mnozi nedoletěli [Muchos no han logrado volver], Praha 1989, p. 60; Svatopluk RUTAR, "Rudolf Bolfík, bojovník proti fašismu - vzpomínka ke 45. výročí úmrtî" [Rudolf Bolfík, combatiente contra el fascismo: Recuerdo en ocasión del 45 aniversario de su muerte], in: Sborník Jižní Morava 22/25, Brno 1986, pp. 306-339; accesible de: http://www.regionrevue.eu/cz/view.php?cisloclanku=2016040001 \&nazevclanku=pred-75-lety-zahynul-v-boji-rudolf-bolfik, [consultado el 10 de agosto de 2018]; Svatopluk RUTAR, "Před 70 lety zahynul v boji Rudol Bolfík" [Hace 70 años pereció en la lucha Rudolf Bolfík], Malovaný kraj: národopisný a vlastivědný časopis Slovácka 2, Břeclav 2011, p. 12. 
terminó sus estudios con los exámenes finales, de nuevo con una nota "buena", en la $48^{a}$ posición. Según la evaluación del jefe de su grupo escolar, Rudolf Bolfík parecía ser más bien un estudiante promedio. En su expediente personal se puede leer que es "negligente, socarrón, tranquilo, trabajador, disciplinado, pero poco enérgico e independiente". Al día siguiente, después de haber aprobado los exámenes finales, este joven de diecinueve años, de cabello y ojos negros, $178 \mathrm{~cm}$ de estatura, se presentó voluntariamente ante la comisión de la Comandancia Distrital Complementaria en la ciudad de Uherské Hradiště y fue reclutado en la Aviación. ${ }^{5}$

El 1 de octubre de 1932, en el aeropuerto de Kbely cerca de Praga, el recién soldado Rudolf Bolfík entró en las filas del Regimiento de Aviación 5, en su escuadra 82/5. Allí se formó en la escuela para suboficiales, terminándola con la clasificación "muy buena", y alcanzando el $10^{\circ}$ lugar del número total de 62 concurrentes a de la misma. Su escuadra fue incluida en la de bombarderos pesados, y armadas con aviones monomotores de 2 plazas Letov $\breve{S}-16$ y también de Fokker de tres motores F-VIIb-3m y F-IX. El 1 de marzo de 1933 fue ascendido a soldado de primera y cinco meses después a cabo. Gracias a la creciente práctica y más experiencia se iba cambiando también su capacitación y profesionalidad. Desde el 1 de febrero de 1932 se desempeñó en la escuadra como mecánico de aviación auxiliar, desde el 28 de marzo de 1933, como mecánico de II clase y, al fin, el 30 de noviembre de 1933 fue nombrado mecánico de aviación militar de I clase. ${ }^{6}$

Después de cumplir el servicio militar obligatorio de dos años, se cambió también su condición de servicio, así que el 1 de octubre de 1934 fue transferido del grupo de personas, que seguían realizando su servicio activo, al grupo de suboficiales reenganchados, es decir, de personas que cobraban sueldo. Pronto después, el 15 de noviembre de 1934, Rudolf Bolfík alcanzó el ascenso al grado de sargento. Asimismo, la evaluación por parte de los oficiales superiores cambió en muchos aspectos, a diferencia de la primera, no demasiado halagadora. En el informe de servicios, elaborado por el comandante suplente de la escuadra 82/5, teniente mayor Oldřich Škop, podemos leer que Rudolf Bolfík tiene "el carácter equilibrado, aunque cerrado, diligente y trabajador, disciplinado, y en calidad de mecánico de I clase es muy bueno". 7 A pesar de que con esta evaluación pudo quedarse, sin duda, en la aviación militar, el 1 de abril de 1935 Bolfík se fue del ejército a la reserva. El mismo indicó que la razón real de este hecho había sido la insistencia de su madre que no había deseado que continuara en el ejército. Cualquiera que fuese el verdadero motivo (y no tiene sentido especular sobre él), es posible considerar como muy probable que en su caso no se haya tratado de ninguna falta contra la disciplina. Por lo menos, los documentos de archivos no indican nada de esta índole. ${ }^{8}$ Como curiosidad podemos mencionar que durante su estancia praguense Rudolf Bolfík descubrió su pasión indiscutible por el arte de fotografiar, lo que demuestran sus fotos del aeropuerto local que se han conservado hasta hoy. La base de este interés

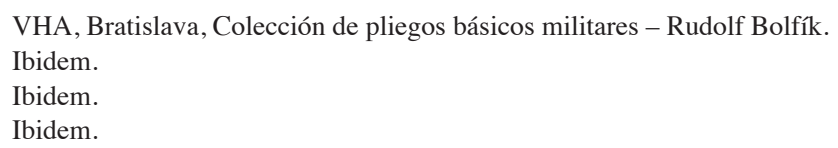


suyo consistía tanto en la "rutina cotidiana" de aeropuerto como las averías o visitas excepcionales que pasaron en aquellos años por el aeropuerto.

Sin embargo, debido a la difícil situación económica en toda la sociedad, la vida fuera del ejército pasó a ser para Rudolf Bolfík una persistente lucha por adquirir un empleo civil correspondiente. Por eso no sorprende que después de estallar la Guerra Civil de España, trató de irse al país detrás de los Pirineos, al igual que lo hicieron otros soldados retirados. Logró realizarlo, como vamos a ver a continuación, pero sólo después de intentarlo varias veces.

Antes de llegar a este punto, sugiero constatar que la afirmación sobre las luchas de Abisinia contra las tropas italianas, ${ }^{9}$ incluso como "el piloto personal del emperador mismo", no está documentada y, por lo tanto, se trata de pura fabulación.

El primer intento de ir a España se realizó probablemente ya en la primavera de 1937. Trató de entrar por su propia cuenta. El 5 de mayo, recogió en Hodonín su pasaporte, recién expedido bajo el número 117/2281-III, que le dio derecho de viajar a Austria, Alemania, Suiza y Francia. Pasó por Praga para cambiar divisas y el 27 de mayo cruzó en Dolní Dvořiště la frontera de su patria. A través de Austria y Suiza llegó a Francia, primero a Ponte du Rhin y luego a París donde visitó la Exposición Universal que tenía lugar precisamente en aquel tiempo. Sin embargo, después volvió a Checoslovaquia; el motivo de su regreso se desconoce..$^{10}$ No conocemos más detalles, pero lo que es casi seguro es el hecho de que los órganos de policía no se enteraron nunca sobre aquella "excursión"; en el caso de que sí, no habría podido vestir el uniforme de gendarme.

Después de regresar, trabajó cierto tiempo en el aserradero de Kohn en Hodonín, ejerciendo su profesión original de electromecánico. No obstante, su padre insistía permanentemente que buscara un empleo más duradero y con más perspectivas. Solamente a base de una reprensión dura de parte de su padre -y seguramente un poco contra su voluntad- presentó su inscripción a la gendarmería. En calidad propia de antiguo suboficial reenganchado cumplió con todos los requisitos necesarios y por parte de los superiores no se presentaron objeciones, así que el 1 de octubre de 1937 fue admitido en la Escuela de Gendarmería para realizar un entrenamiento teórico en la Comandancia Complementaria de Gendarmería de Brno. ${ }^{11}$ De esta manera se abrió ante él una exigente carrera de gendarme, pero a la vez bastante interesante,

9 Svatopluk RUTAR, "Na kř́́dlech za svobodou" [En las alas por la libertad], Malovaný kraj XIX/4, Břeclav 1983, p. 3.

10 MZA, Brno, Fondo de la Comandancia Provincial de Gendarmería (Zemské četnické velitelství) Brno B 72, cartón 169, sign. 7860: La carta de la Jefatura del Dpto. Complementario de Gendarmería acerca del asunto de Rudolf Bolfík, del 17 de diciembre de 1937; S. RUTAR, "Rudolf Bolfík", pp. 306-309; idem, "Na kř́́dlech", p. 3.

11 VHA, Bratislava, Colección de pliegos básicos - Rudolf Bolfík, MZA, Brno, Fondo de la Comandancia Provincial de Gendarmería (Zemské četnické velitelství), Brno B 72, cartón 169, sign. 7860: Disposición de la Comandancia Provincial de Gendarmería de Brno, el 1 de octubre de 1937; HOŠEK, "Čs. Interbrigadistê"; František HELEŠIC, "Z galerie statečných - Rudolf Bolfík" [Galería de los valientes - Rudolf Bolfík], Hlas revoluce 5, Praha 1984; František KEJíK, "Dlaň člověka" [Palma del hombre], Obrana lidu, el 25 de diciembre de 1959. 
que figuraba entre los empleos relativamente bien pagados y le aseguraba también una sólida seguridad social.

La carrera de gendarme de prueba de Rudolf Bolfík duró poco tiempo, menos de dos meses. Durante las primeras vacaciones confió a su hermano Ladislav que el servicio de gendarme no le gustaba: "Yo no puedo estar allí. No puedo entrar en una casa, ponerle a un obrero las esposas. Su mujer e hijos llorarían y yo no lo aguantaría tampoco, me pondría a llorar junto con ellos." 12 Y así pasó, el 28 de noviembre de 1937 abandonó el Cuartel de Gendarmería de Brno, sin indicar la razón, y desapareció. Como en aquel entonces se trataba de una infracción de servicio bastante grave, la Estación de Investigación de Gendarmería de Brno empezó con la busca del desertor, inmediatamente el 30 de noviembre, extendiéndola a todas las direcciones de policía, autoridades policíacas estatales y estaciones de pesquisa en el territorio de la República de Checoslovaquia, y el 16 de diciembre, el Tribunal de División de Brno emitió la orden de arresto. Los órganos oficiales trataron de adquirir la información sobre la causa de su escape, sometiendo a sus colegas a interrogatorios. Con base de ellos, los órganos de seguridad tenían la sospecha de que trataría de ir a Rusia, donde trabajaba supuestamente su tío en una compañía aérea ya que Bolfík había mencionado esa variante varias veces en algunas conversaciones. ${ }^{13}$ Aproximadamente tres semanas después -4 de enero de 1938- la misma autoridad anuló de repente la pesquisa y la orden de arresto. ¿Qué pasó en realidad?

Un día antes de la Noche Vieja de 1937, a Rudolf Bolfík lo detuvieron en el paso de frontera en Horní Dvořiště de la Bohemia del Sur. Su detención significó el final de su segundo intento de viajar a la España combatiente. La situación de cómo aconteció todo, la describe un informe de la Estación de Gendarmería local en Horní Dvořiště, distrito Kaplice.

El 30 de diciembre de 1937, Rudolf Bolfík fue transportado de Austria a Horní Dvořiště, donde fue detenido después de desertar de la escuela para el entrenamiento de gendarmes de prueba. Bolfík declaró que había salido de Brno en tren a Bratislava. De allí se fue a Petržalka y después clandestinamente a Austria, sin el pasaporte válido. En el territorio austríaco tomó el ferrocarril eléctrico en dirección a Viena, después partió para Insbruk y Bludenz y de allí se fue caminando a Suiza. En Basilea Bolfík fue detenido por los órganos de seguridad y devuelto a Austria. En Austria se presentó en el Consulado checoslovaco donde le instruyeron que fuera a la policía estatal que lo llevaría a su patria, si no tenía dinero para pagar el billete de viaje, lo que Bolfík hizo. Rudolf Bolfík no comunicó a los órganos de seguridad austríacos que era desertor y, por lo tanto, no le interrogaron acerca de los asuntos referentes al ejército y gendarmería. En calidad de excusa, Bolfík dijo que había querido visitar a su novia Františka Fuchsová en París, a quien conoció allí en mayo de 1937. En cuanto a la deserción, Bolfík indicó que no había sido incitado por nadie, que no se había confiado a nadie con su intención.

12 RUTAR, “Na křídlech", p. 3.

13 MZA, Brno, Fondo de la Comandancia Provincial de Gendarmería (Zemské četnické velitelství), Brno B 72, cartón 169, sign. 7860: Complemento del informe No. de referencia 667, del 30 de noviembre de 1937, escrito el 2 de diciembre de 1937. 
Según el informe anterior es evidente que durante el interrogatorio Rudolf Bolfík trató de disimular, no mencionó el objetivo real de su viaje, ni la razón de su detención en Basilea. Trató de minimizar las consecuencias de su actuación, las que a pesar de eso fueron serias. ${ }^{14}$

Con este hecho llegamos a la cuestión de si la real razón de la huida de Rudolf Bolfík de la Escuela de Gendarmería de Brno fue el anhelo de ir a la España republicana, o si esa posibilidad apareció después, como consecuencia lógica de su escape causado por otra razón, cuya causa fue completamente distinta. Los documentos fragmentarios de los archivos no nos ofrecen una respuesta tajante, por eso hay que tener cuidado con las afirmaciones de historiadores y publicistas del período de normalización. Sin embargo, en este caso tienen probablemente cierto fundamento porque Rudolf Bolfík, de orientación izquierdista, fue por lo menos simpatizante del Partido Comunista de Checoslovaquia (en adelante solo KSČ). Los motivos idealistas de un hombre de veinticuatro años predominaron la perspectiva de una existencia relativamente estable en el cuerpo de gendarmería.

De todas maneras, después de su detenimiento en Horní Dvořiště fue escoltado a Checoslovaquia y encarcelado en la prisión del Cuartel de České Budějovice. Como desertor del ejército tuvo que llevar las consecuencias de su actuación, le esperaba el juzgado militar. El proceso fue llevado en el Tribunal de División en la ciudad de Pilsen, bajo la presidencia del JUDr. Jaroslav Lička; a base de los $\S \S 183$ a 199 de la Ley Penal fue declarado culpable y el 1 de febrero de 1938 fue condenado sin lebrtad incondicional de tres meses de presidio, agravada cada quince días con un lecho duro y la incomunicación durante las primeras y últimas dos semanas de la prisión. El tribunal constató lo siguiente:

El acusado reconoció las circunstancias del delito, confesando expresamente también su intención de desertar. El servicio de gendarmería no le gustó y por lo tanto huyó del país con la idea de buscar un empleo en Francia, eludiendo para siempre el servicio de gendarmería para la que no convenía en absoluto. Aunque no hubiera existido la confesión del demandado, su intención de desertar resulta de los hechos averiguados, es decir, escapó en el vestido civil y regresó sólo cuando se le acabó el dinero. Al establecer la pena, al inculpado le agravió el hecho de que había huido al extranjero, dificultando de esta manera su detención, así como la grave violación de los deberes importantes del suboficial y gendarme de prueba. A la vez, la circunstancia atenuante fue su confesión e irreprochabilidad.

La condena tuvo también otras consecuencias. Naturalmente, siguió no sólo la despedida del Cuerpo de Gendarmería, sino también con la misma decisión del Tribunal de División, a base de la sentencia, fue degradado de sargento de reemplazo

14 MZA, Brno, Fondo de la Comandancia Provincial de Gendarmería (Zemské četnické velitelství), Brno B 72, cartón 169, sign. 7860: Informe sobre la detención de Rudolf Bolfík, Estación de Gendarmería en Horní Dvořiště, distrito Kaplice, 31 de diciembre de 1937, NA, Praha, Fondo de la Dirección de Licencias, Praga II. - Oficina General - 1931-1940, cartón 4839, sign. B 2312/44, Bolfík Rudolf; RUTAR, “Rudolf Bolfík”, pp. 306-309. 
a mero soldado. Tuvo que cumplir toda la pena en el presidio Bory, de mala fama, en la ciudad de Pilsen. ${ }^{15}$

La estancia forzada en la prisión profundizó probablemente la orientación izquierdista de Rudolf Bolfík, intensificada con la compañía de otros presos, miembros o simpatizantes del Partido Comunista. Después de salir de la cárcel, antes de la Pascua de 1938 volvió a casa, pero por poco tiempo. Su padre -por cuya insistencia empezó a estudiar en la Escuela de Gendarmes- se desligó de él.

Debido a los anteriores intentos no exitosos, Rudolf decidió organizar ya la tercera partida al extranjero, esta vez en colaboración con el órgano central del Partido Comunista KSČ. Después de adquirir legalmente el pasaporte, pasó la frontera a Alemania y llegó a Francia el 20 de mayo de 1938; a finales del mes, entró por fin en la España republicana combatiente. ${ }^{16}$ En aquel período, la recluta a las Interbrigadas ya se había prácticamente estancado. Rudolf Bolfík pasó a ser uno de los últimos interbrigadistas checoslovacos. Por desgracia, no logró aprovechar su profesión original, su experiencia de mecánico de aviación; de todas maneras, entre los recién llegados no fue ni el primero ni el último.

Igualmente que en el caso de otros combatientes, las informaciones sobre su participación en las luchas de España son escasas. ${ }^{17}$ Coinciden más o menos en la constatación de que a finales de mayo de 1938 llegó a España y llegó a ser miembro del Batallón Divisionario.

El $45^{\circ}$ Batallón Divisionario fue una importante unidad de infantería, con una representación relativamente numerosa de voluntarios checoslovacos. Originalmente se trataba del batallón balcánico, llamado a veces el Batallón Checo-Balcánico de Infantería, formado en los primeros meses de 1938 como parte de la 129ª Interbrigada. Sin embargo, todavía en la etapa de formación tuvo que ser utilizado urgentemente contra la ofensiva franquista en Aragón y después sus partes destrozadas retrocedieron hasta el río Ebro. Los miembros del batallón que se quedó sin contacto con otras unidades, bloqueadas en el Levante, se concentraron al comienzo de abril de 1938 en la costa catalana. Allí, no lejos de Tarragona, formaron un nuevo batallón, junto con los antiguos miembros del Batallón de Masaryk y Dimitrov, aislados al retroceder de sus unidades. Como aquel batallón no fue incluido en ninguna Interbrigada, sino fue sometido al mando de la 45ª División (Cmdte. Hans-Kahle), empezó a llamarse Divisionario. Como la fecha oficial de su surgimiento se indica

15 VHA, Bratislava, Colección de pliegos básicos - Rudolf Bolfík; MZA, Brno, Fondo de la Comandancia Provincial de Gendarmería (Zemské četnické velitelství), Brno B 72, cartón 169, sign. 7860: Rozsudek divizního soudu v Plzni s Rudolfem Bolfíkem z 1. února 1938 (Sentencia del Tribunal de División de la ciudad de Pilsen, juzgado de Rudolf Bolfík del 1 de febrero de 1938); HOŠEK, "Čs. Interbrigadistê".

16 NA, Praha, Fondo de la Unión de Combatientes Antifascistas (Svaz protifašistických bojovníků), Comité Central - Praga - cuestionarios: Helena Bolfíková; RUTAR, "Rudolf Bolfík”, pp. 306-309.

17 Archivo Histórico Provincial de Albacete, comunicación al autor del 31 de agosto de 2008; Archivo General Militar de Ávila, comunicación al autor del 1 de mayo de 2008; Archivo Histórico del Ejército del Aire en Villaviciosa de Odón, RF08 No. 309, comunicación al autor del 27 de marzo de 2008; HOŠEK, "Čs. Interbrigadistê". 
el 1 de mayo de 1938, pero en realidad se trata de la fecha del desfile antes de la salida al frente.

El Batallón Divisionario participó primero, en mayo de 1938, en las batallas de defensa en el frente de Tortosa, cerca de la desembocadura del río Ebro. Mientras que tres compañías de infantería tomaron posiciones de combate en la costa, la compañía de ametralladoras se quedó en el castillo antiguo, con lo que se impidió al enemigo cruzar el río en aquel espacio. Unos dos meses después, el mando dislocó el Batallón Divisionario a la desembocadura del Ebro, al pueblo Aldea, donde una parte, junto con la compañía de voluntarios franceses, realizó el forzamiento del río Ebro, con el objetivo de desviar la atención del enemigo del lugar donde las tropas republicanas a finales de julio de 1938 realizaban la travesía principal del río. Las unidades conquistaron la ciudad de Amposta, en la que durante todo el día y noche se defendieron contra la superioridad numérica del enemigo hasta la orden de retirarse. Después de la exitosa travesía republicana del Ebro, el Batallón se desplazó a la otra orilla, ocupó la posición al lado de la villa Corbesa en la Sierra Pandol y participó en el ataque en progresión.

La última gran ofensiva de los republicanos que debía conjurar el peligro de la amenaza de Valencia y unir de nuevo el territorio republicano, dividido en dos partes, marchaba al comienzo relativamente bien. Después de ampliar la cabecera de puente en la otra orilla, las unidades del Ejército Popular de la República empezaron a penetrar en la profundidad de la zona de la defensa del enemigo. Los franquistas concentraron refuerzos de otros sectores y después de unos días pararon el avance republicano. Los crueles combates de posiciones duraron más de tres meses. La gran ofensiva republicana en el Ebro, en la que la parte gubernamental perdió una cantidad considerable de sus unidades en condiciones de combatir, representó a la vez el escenario de la última actuación combativa de las Interbrigadas en su conjunto. ${ }^{18}$

Rudolf Bolfík luchó en el pelotón encabezado por Alois Soběslavský, y participó en los combates defensivos de Tortosa y, más tarde, en la misma desembocadura del Ebro. En el transcurso de las operaciones fue herido supuestamente tres veces. Lo que es seguro es que del 9 al 26 de octubre de 1938, después de la última herida, fue ingresado en el hospital de Vichy. ${ }^{19}$ A veces se indica, que se desempeñó como mecánico de aviación, según su calificación militar checoslovaca, pero parece que esta información probablemente no podrá corroborarse. En todo caso, se quedó en España hasta el final, participó en la valiente defensa de Barcelona y como soldado del Ejército de Modesto protegió el repliegue de las unidades republicanas a través de los Pirineos. Asimismo, allí el mero simpatizante del Partido Comunista llegó a ser su militante.

18 Véase más información sobre la actividad de los voluntarios checoslovacos en el Batallón Divisionario, por ejemplo, Petr LUKEŠ, “Španělská válka interbrigadisty Adolfa Vodičky” [La guerra española del interbrigadista Adolf Vodička], in: 70. výročí ukončení španělské občanské války 2 [El 70 aniversario del fin de la Guerra Civil Española], (=Sborník Muzea dělnického hnutí [Almanaque del Museo del Movimiento Obrero]), Praha 2009, pp. 65-66, J. RAJLICH - D. MAJTENYI, "Jan Ferák", pp. 113-120.

19 RUTAR, “Rudolf Bolfik", pp. 306-309. 
Después le esperaba una penosa anábasis, al igual que a otros centenares de nuestros interbrigadistas que permanecieron en España hasta el final. Rudolf Bolfík pasó la frontera francesa el 10 de febrero de 1939, al día siguiente. Cuando Francia, después de cierta vacilación abrió sus fronteras del sur a los fugitivos. Llegó al país que hace tiempo fue amigo. Figuró entre más de seiscientos voluntarios, ciudadanos de la antigua Checoslovaquia antes del pacto de Munich, a quienes les esperaba un destino similar de fugitivos, sin posibilidad de volver a su patria. Siguió una internación forzada en los campamentos instalados con este fin, en el caso de Bolfík primero en Argéles-sur-Mer y más tarde, a partir del mes de mayo del mismo año, en el campamento Gurs, de mal renombre, que se encontraba al pie de las pendientes del norte de los Pirineos, en el departamento de Pau. ${ }^{20}$

El estallido de la guerra en septiembre de 1939 significó un cambio brusco en la vida de los internados y la posibilidad de entrar en nuestro ejército, así como la oportunidad de liberarse de la vida forzada del campamento. De esta manera, Rudolf Bolfík logró entrar en nuestro ejército, como uno de los primeros del grupo de los interbrigadistas internados. Sin duda, ocultó exitosamente su membresía en el Partido Comunista y asimismo el hecho de que había desertado del curso preparatorio de gendarmes y había sido degradado a mero soldado. Debido a que los órganos militares checoslovacos no tenían prácticamente ninguna documentación de comparación, tuvieron que apoyarse sólo en lo dicho por el recluta mismo. Entonces el 18 de diciembre de 1939, Rudolf Bolfík fue presentado como sargento en el Cuerpo Suplementario del Ejército Checoslovaco en Agde y fue incluido, junto con otro interbrigadista Vincenc Kocman, en la Aviación. El juramento militar solemne lo empeñó en ocasión del gran desfile de tropas checoslovacas en Agde, el 7 de marzo de $1940 .^{21}$

Como se trataba de un mecánico de aviación con calificación especializada, profesión que al comienzo escaseaba considerablemente en la Aviación checoslovaca, su regimentación fue decidida rápidamente. Después de una readaptación correspondiente al mantenimiento de la técnica de aviación francesa, el 8 de marzo de 1940 fue enviado directamente al frente. Junto con otro mecánico del personal de tierra, el cabo Stanislav Šnepfenberger, fueron incluidos en la unidad de caza de la Aviación francesa Groupe de Chase 1/1, en la que ya prestaban su servicio seis pilotos checoslovacos (en el transcurso de la guerra dos de ellos quedaron en la estacada $\mathrm{y}$ otros dos sufrieron graves heridas). ${ }^{22}$

20 Véase más detalles sobre la problemática de los campamentos de internación, por ejemplo, Jiří FRIEDL, “'Španěláci’ z tábora Gurs. Ke vstupu čs. Interbrigadistů do naší armády ve Francii 19391940" ["Gallegos" del campamento Gurs. Acerca de la entrada de los interbrigadistas checoslovacos en nuestro ejército en Francia 1939-1940], Historie a vojenství 4, Praha 2001, pp. 806-823.

21 VHA, Bratislava, Colección de pliegos básicos - Rudolf Bolfík; Josef VÁŇA - Jan RAIL, Českoslovenští letci ve Francii 1939-1940 [Aviadores checoslovacos en Francia 1939-1940], Praha 2005, p. 69.

22 En GC I/1 sirvieron los siguientes seis pilotos de caza: el teniente mayor Rudolf Fiala (herido en el combate aéreo el 26 de mayo de 1940), el sargento Josef Pípa, el cabo Cyril Nováček (herido el 9 de julio de 1940), el teniente mayor Jiř́i Král (pereció en el combate aéreo el 8-VI-1940), el sargento Jan Krákora (pereció en el accidente aéreo el 23 de abril de 1940) y el cabo Jindřich Poštolka. Jiří 
El GC I/1, rearmado hace poco con nuevos aviones caza Marcel Bloch MB-152, tuvo su base en el aeropuerto de Chantilly-les-Aigles, el que fue antes un hipódromo, a 40 kilómetros del norte de París. En el período de la llamada "guerra extraña" no realizaba todavía grandes actividades combativas, pero eso habría de cambiar pronto. El 10 de mayo de 1940, al amanecer, el ejército alemán comenzó su campaña militar de oeste y el GC I/1, junto con sus miembros checos, apareció en el centro del mayor fuego. Un vuelo tras otro, dos o tres acciones combativas al día ponían altas exigencia no sólo en los pilotos, sino también en el personal de tierra.

Es conocido que la campaña francesa tuvo un transcurso inesperado, dramático y fatal para las tropas de Aliados. En cuanto el ejército alemán obligó a las tropas belgas y holandesas a la capitulación y expulsó el cuerpo expedicionario británico hacia atrás, a las islas, inició el 5 de junio su avance al interior francés. Asimismo, el valiente GC I/1 tuvo que retroceder y junto con él vivió la agonía final y la amarga retirada también el sargento Bolfík. El 6 de junio se desplazaron al aeropuerto Chavenay-Villepreux, situado a 15 kilómetros al oeste de Versailles, pero resistieron allí solamente cuatro días. El 10 de junio, el GC I/1 se dirigió al sur, al aeropuerto Janville, situado al sur de Etampes, y tres días más tarde se fue al aeropuerto Les Vignots, que se encontraba a 15 kilómetros al norte de Châteauroux. Allí, el 17 de junio, recibieron la noticia de que el nuevo primer ministro francés, mariscal Pétain, pidió al enemigo que le comunicara las condiciones de armisticio. El mismo día, el GC I/1 se retiró a Rochefort, a 30 kilómetros del puerto La Rochelle en la costa atlántica de la Francia de sudoeste. Dos días después retrocedieron a otro aeropuerto en la costa del Atlántico, Royan-Médis, donde terminaron su actuación combativa.

Sólo un día antes de la capitulación francesa, el 21 de junio de 1940, el comandante francés del GC I/1 liberó del servicio a los últimos cuatro pilotos checoslovacos para que pudieran continuar el combate en otra parte. Después de despedirse de sus compañeros de lucha franceses, los pilotos, sargentos Josef Pípa y Jindřich Poštolka, junto con los mecánicos, sargento Rudolf Bolfík y cabo Stanislav Šnepfenberger, se dirigieron al sudeste, en dirección hacia el puerto mediterráneo Port Vendres adonde se retiraron también otros grupos de aviadores checoslovacos. El 24 de junio de 1940, salió del muelle el barco Meonia, a bordo se encontraba un grupo de pilotos checoslovacos evacuados, encabezados por el capitán de aviación Emil Bušina. Después de desembarcarse en el Orán norteafricano continuaron en tren a la Casablanca marroquí y de allí el 29 de junio a Gibraltar, en el barco Gibel-Dersa, con el convoy bajo el mando del capitán de aviación Alois Hlobil. El convoy completado con otros pilotos zarpó de este dominio británico el 2 de julio, en el barco Neuralia y después de una navegación dramática ancló en el puerto de Liverpool. ${ }^{23}$

En la segunda mitad de julio de 1940, reinó entre los miembros checoslovacos de unidades terrestres en las islas británicas, evacuados de Francia, una tensa y

RAJLICH, Na nebi sladké Francie. Válečný deník československých letců ve službách francouzského letectva 1939-1945 [En el cielo de la dulce Francia. Diario de guerra de aviadores checoslovacos en el servicio de la Aviación francesa 1939-1945], Cheb 2008, pp. 1101-1114.

23 Ibidem, pp. 1001 y 1114. 
nerviosa atmósfera. En aquel tiempo culminaron los acontecimientos, conocidos más tarde como la crisis de Cholmondeley, o también como "la rebelión en Cholmondeley". Ante nuestro gobierno de exilio se presentó una situación con un resabio muy amargo, cuyas raíces se pueden encontrar ya en los últimos días de la catástrofe francesa, seguida por la evacuación de nuestros soldados por el mar, a los cuales esperaba en la islas británicas un futuro extremadamente inseguro. Estos aspectos, relacionados con el comportamiento criticado de una parte de nuestro cuerpo de comandantes durante la campaña francesa, provocaron en algunos de nuestros soldados un sentimiento de injusticia, supuesta o real, y una considerable frustración, acompañada además por una peligrosa desmoralización interna. De esta manera se creó un terreno y micelio muy fértil para una agitación comunista que se realizaba exactamente dentro del marco de las intenciones de Comintern: de que se trataba de una guerra imperialista y no tenía sentido participar en ella o, más bien, continuar en ella. Con esta agitación subversiva se contagió una parte considerable de checoslovacos evacuados, con excepción de algunos integrantes de la tropa. La desunión amenazante fue conjurada por fin, pero por un precio relativamente alto: 539 soldados, en total, abandonaron el ejército, incluyendo un ciento de antiguos interbrigadistas. El 27 de julio de 1940, todos fueron excluidos de las fuerzas armadas checoslovacas; los oficiales y suboficiales fueron degradados y seguidamente internados. Después de cierto tiempo una mayor parte de ellos entró en los cuerpos auxiliares Pioneer Corps. El cambio de su opinión y la revalorización de la situación se produjo con base a los acontecimientos después del 22 de junio de 1941 y la entrada de la URSS en guerra. Luego, en el transcurso del siguiente año, 1942, una mayor parte del equipo rebelde, participantes del motín, volvió a las unidades de nuestro ejército. Desde el punto de vista jurídico fue la abolición del Presidente de la República en diciembre de 1941 que puso el punto final a este asunto tan desagradable para nuestro movimiento de Resistencia, relacionado con los acontecimientos del verano de 1940. Y fueron precisamente "los gallegos"-indoctrinados por medio de la dirección extranjera del Partido Comunista checoslovaco con las órdenes de Comintern- que tuvieron parte leonina en la situación surgida y fueron líderes de toda la rebeldía. ${ }^{24}$

Después de su llegada a Inglaterra, al campamento del Ejército Checoslovaco en Cholmondeley, el sargento Rudolf Bolfík, a pesar de que era comunista, no se afilió a estas fuerzas izquierdistas que prevalecían y rechazaban al comienzo la obediencia al mando militar y político, creando así un ambiente subversivo que culminó con los acontecimientos descritos. Es probable que no nos enteremos de si Bolfík manifestó cierta solidaridad en este caso porque no fue integrante de unidades de tierra, sino ya en Francia fue regimentado en la aviación. En todo caso fue uno de los 44 antiguos interbrigadistas que no se sometieron a la propaganda comunista,

24 Véase más información acerca de la problemática de los acontecimientos en Cholmondeley en el verano de 1940 en un estudio muy acertado del último tiempo: Jiří PLACHÝ, "Vzbouřenci z Cholmondeley 1. část" [Rebeldes de Cholmondeley, Ia parte], Historie a vojenství 3, Praha 2016, pp. 19-38; idem, "Vzbouřenci z Cholmondeley 2. část" [Rebeldes de Cholmondeley, II a parte], Historie a vojenstvi 4, Praha 2016, pp. 20-57. 
no participaron en la rebelión y se quedaron en las unidades checoslovacas en Gran Bretaña. ${ }^{25}$ De esta manera guardaban una evidente distancia de la decisión de sus antiguos compañeros de combate y se quedaban aparte de sus esfuerzos de agitación. Por desgracia, Bolfík figuró a la vez entre los cinco soldados de este grupo que en la lucha posterior perdieron la vida.

Rudolf Bolfík se integró primero en el llamado Grupo de Bombardeo que representaba un embrión organizativo de la escuadra de bombardeo que se constituía en aquel entonces. La primera parte del grupo la formó en el campamento de Innsworth Lane, cerca de Gloucester, el personal checoslovaco, evacuado de Francia. Más tarde, en la base aviática de Cosford cerca de Wolverhampton, a Rudolf Bolfík, con el grado AC2, lo regimentaron para el período de guerra en las RAF VR. ${ }^{26}$ Perteneció a los miembros fundadores de la $311^{\text {a }}$ Escuadra checoslovaca de bombardeo y de Cosford lo desplazaron a la nueva base en Honington, en el condado de Sulfolk. A pesar de su especialización original, Rudolf Bolfík no pasó a ser integrante del personal de tierra, como se podía suponer. Quería luchar ante todo y por eso, igualmente que Vincenc Kocman, presentó voluntariamente su inscripción en el curso de tiradores de a bordo, incorporándose el 18 de agosto de 1940. Después de terminar el curso -siendo sargento mayor- fue graduado al rango británico Sergeant e incluido en el ala operativa de la escuadra.

Rudolf Bolfík debía recibir su bautismo de fuego en la noche del 16 al 17 de diciembre de 1940. Aquel día la 311 a Escuadra envió sus cuatro Wellington Mk.IC al ataque aéreo de Mannheim alemán. En uno de los aviones, T 2519 (KX-Y), fue el propio S/Ldr Percy Ch. Pickard, DFC quien "conducía" por primera vez la tripulación de novicios y precisamente en su avión debía estar también como tirador de proa el Sgt. Rudolf Bolfík. Sin embargo, todo sucedió de otra manera y por razones desconocidas fue sustituido por el instructor inglés Sgt. Leo J. Judson. ${ }^{27}$

El cuarto vuelo de combate por encima del territorio hostil lo emprendió Bolfík en la noche del 16 al 17 de enero 1941. Al mismo tiempo, se trataba de su último vuelo... Bomber Command británico envió en total 81 bombarderos para realizar el ataque aéreo al puerto Wilhelmshaven de Sajonia Baja, en el que fue anclado el buque de combate Tirpitz. Entre los aviones que atacaban al puerto defendido fuertemente se encontraban también cinco aparatos de la $311^{\text {a }}$ Escuadra. Uno de los aviones fue T2519 (KX-Y) P/O de Antonín Kubizňák. Algunas tripulaciones no lograron llegar al punto de destino y por lo tanto tuvieron que bombardear los blancos aéreos de relevo. El avión P/O de Kubizňák, con Rudolf Bolfík en la cabina de proa,

25 PLACHÝ, "Vzbouřenci", p. 33.

26 Con base en la aceptación de Rudolf Bolfík en las RAF le fue asignado el número 787583. Josef VÁŇAJohn SIGMUND - Emil PADIOR, Př́islušníci československého letectva v RAF [Miembros de la Aviación checoslovaca en las RAF], Praha 1999, p. 272, Jmenný seznam př́slušníkủ československé zahraniční armády na západě, část I. A-K [Lista nominal de los miembros del Ejército Checoslovaco extranjero en el Oeste], Praha 2011, p. 68. Accesible de: http://www.acr.army.cz/acr/raf/seznam/b .htm, [consultado del 4 de mayo de 2018].

27 VÚA - VHA, Praha, Fondo ČSL-VB, sign. 680/BI/1/182. Válečný deník 311. peruti [Diario de guerra de la $311^{\text {a }}$ Escuadra], sign. 687/BI/1-6/183. No. 311 Squadron Operations Record Book. 
cumplió con el bombardeo del blanco aéreo, pero al regresar sufrió una avería en el Mar del Norte por causa de la escarcha y de mal tiempo.

El testimonio de la tragedia nos la presentan los registros de radiotelegrafistas del aeropuerto. Primero a las 21.36 hras., captaron la noticia de que el avión tenía una falla del motor, poco después el radiotelegrafista del avión P/O Leskauer emitió la primera señal de socorro, lanzando un S.O.S y pidiendo dos veces que apuntaran la posición del avión. En una fuerte tormenta de nieve, el navegador del P/O Hudec perdió probablemente la orientación. Y es que a las 21.47 hras. Leskauer preguntó si ya se encontraban por encima de Honington (!), lo que hizo de nuevo a las 21.56 hras., cuando su posición no se había cambiado prácticamente. Evidentemente, el P/O de Kubizňák andaba perdido. A las 22.18 hras. el servicio terrestre del aeropuerto captó la señal S.O.S. de Leskauer por la última vez. El avión fue apuntado en la posición de 52.80 de latitud septentrional, 02.41 de longitud este, es decir, por encima del Mar del Norte, a 65-70 kilómetros aproximadamente de la costa británica. A las 22.21 hras, Leskauer transmitió la última señal de código probablemente como el último "adiós" y quedó en silencio. Para siempre.

Como se conocía más o menos su última posición, el mando superior del $3^{\mathrm{er}}$ grupo de Bomber Command dedicó muchos esfuerzos para salvar la tripulación. Desde el amanecer hasta el atardecer lo buscaban once tripulaciones de los aeropuertos Feltwell, Watton, East Wretham y Honington, pero a pesar de esta gran acción, la búsqueda no salió exitosa.

Debido a un fuerte oleaje, viento glacial y la temperatura del agua de sólo cuatro grados sobre cero, los seis miembros de la tripulación no pudieron sobrevivir en el mar mucho tiempo, aunque después de un amerizaje de emergencia hubieran logrado salvarse en el bote salvavidas de goma (dinghy). El avión de Kubizňák fue uno de los cuatro buscados aquella noche por las RAF. Después de pasar el plazo de siete meses, el 25 de agosto de 1941, todos los miembros de la tripulación fueron declarados muertos. ${ }^{28}$

Así terminó la peregrinación de Rudolf Bolfík quien en el año de 1938 abandonó su patria para luchar primero en España y después en Francia y Gran Bretaña. Junto con él encontraron la muerte en la frías olas del Mar del Norte también Antonín Kubizňák, Bohuslav Baumruk, Josef Hudec, Jindřich Leskauer y Jaromír Král. La tumba de toda la tripulación es un cruel e inhospitalario mar, al oeste de las islas neerlandesas de Frisia donde duermen su eterno sueño.

Como sus cuerpos no se han hallado, sus nombres y apellidos están grabados en el monumento conmemorativo de Air Forces Memorial en Runnymede inglés, cerca del castillo de Windsor. El monumento, administrado por la Comisión para sepulcros de guerra de la Comunidad de Naciones británica (Commonwealth War

28 Jiří RAJLICH, Na nebi hrdého Albionu. Válečný deník československých letců ve službách britského letectva 1940-1945 2. část (1941) [En el cielo del orgulloso Albión. Diario de guerra de aviadores checoslovacos en el servicio de la Aviación británica 1940-1945, 2ª parte (1941)], p. 19. Idem, $N a$ nebi hrdého Albionu. Válečný deník československých letcu ve službách britského letectva 19401945. 7. část - Černá kronika čs. letectva v RAF 1940-1945 [En el cielo del orgulloso Albión. Diario de guerra de aviadores checoslovacos en el servicio de la Aviación británica, 1940-1945, $7^{\mathrm{a}}$ parte Crónica negra de la Aviación checoslovaca en las RAF 1940-1945], p. 131. 
Graves Commision, CWGC), está consagrado a la conmemoración de aquellos aviadores quienes sacrificaron sus vidas y sus tumbas son desconocidas. En 360 paneles se indican 20547 nombres ${ }^{29} \mathrm{El}$ nombre de Rudolf Bolfík, oriundo de Mikulčice, se encuentra en el panel No. $39 .{ }^{30}$ Su nombre se recuerda también en el panteón familiar en su pueblo natal.

(Traducido al español por Anna Mištinová)

\section{ANEXO - FOTOGRAFÍAS}

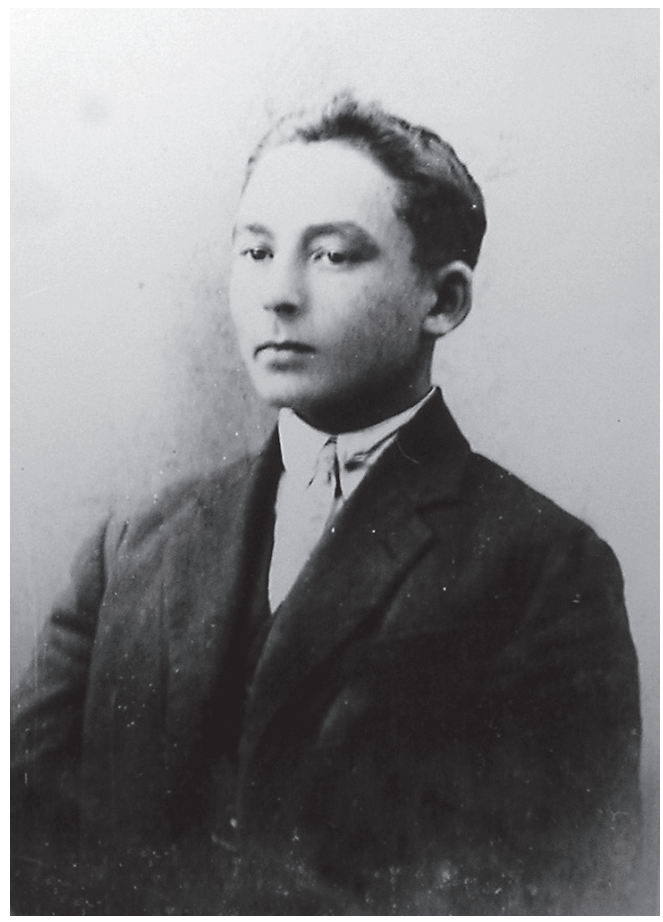

1 - Rudolf Bolfík, oriundo de Mikulčice, en los años de aprendizaje. Ya en aquella edad al muchacho, dotado de talento técnico, y futuro mecánico le fascinaban los aviones. (Fuente: colección personal de D. Majtenyi).

29 El Monumento conmemorativo de Runnymede está consagrado a los desaparecidos, hombres y mujeres, de las Fuerzas Armadas de Gran Bretaña (RAF a WAAF) y de Commonwealth (RCAF, RAAF, RNZAF, SAAF a RIAF), mientras que la Aviación Marítima Británica (FAA) tiene un monumento similar en Lee-on-Solent. El número correcto debe ser ahora 20435 nombres, ya que en los tres decenios posteriores a la inauguración de monumento (1953) se han localizado 112 tumbas de aviadores. Véase Guide to the Air Forces Memorial Runnymede, Surrey, Maidenhead 1985.

30 Ibidem; LOUCKÝ, “Mnozı̊’, p. 60. 


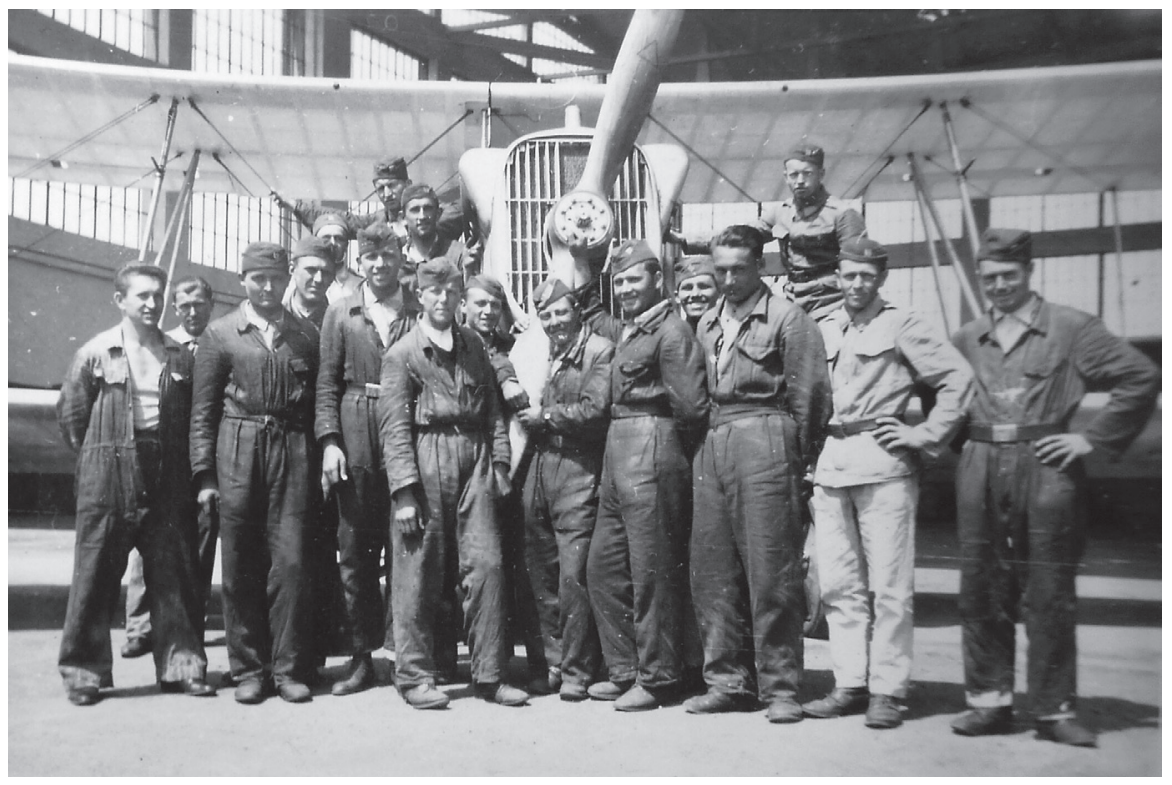

2 - Rudolf Bolfík (de pie, el tercero de la derecha), junto con los miembros del personal de tierra, durante su trabajo en el aeropuerto praguense de Kbely, delante del avión de prácticas Praga E-41. (Fuente: MZA via T. Baletka).

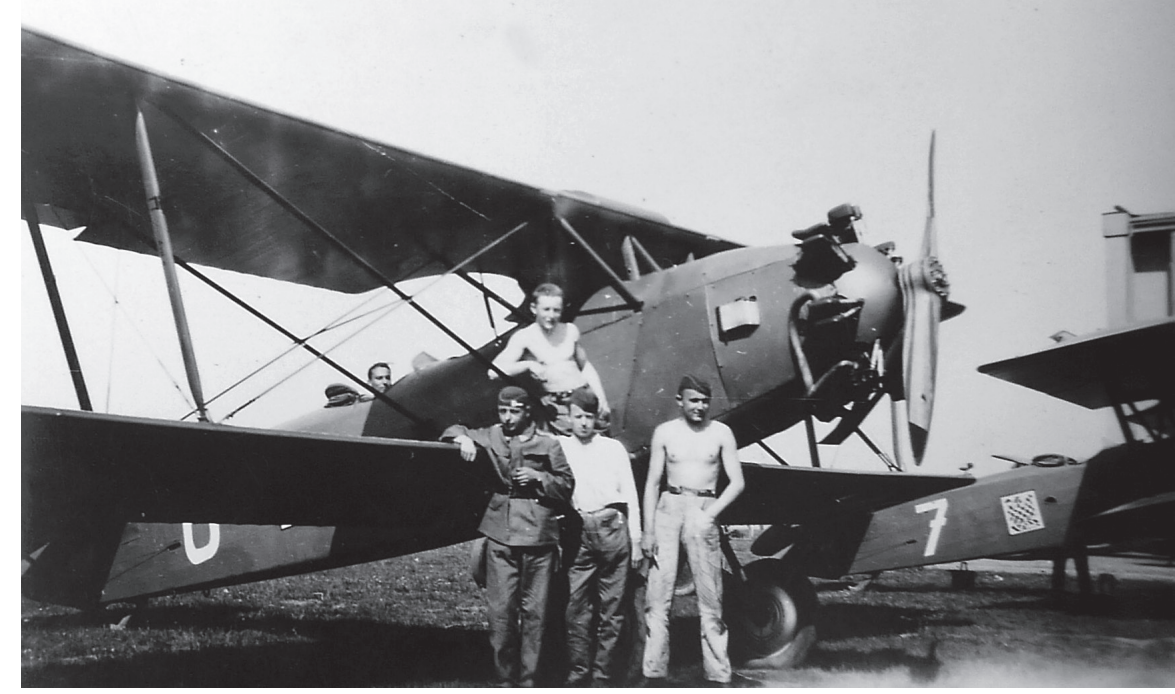

3 - En esta foto se ve en la cabina del aparato de prácticas, tipo Aero A-211. (Fuente: MZA via T. Baletka). 


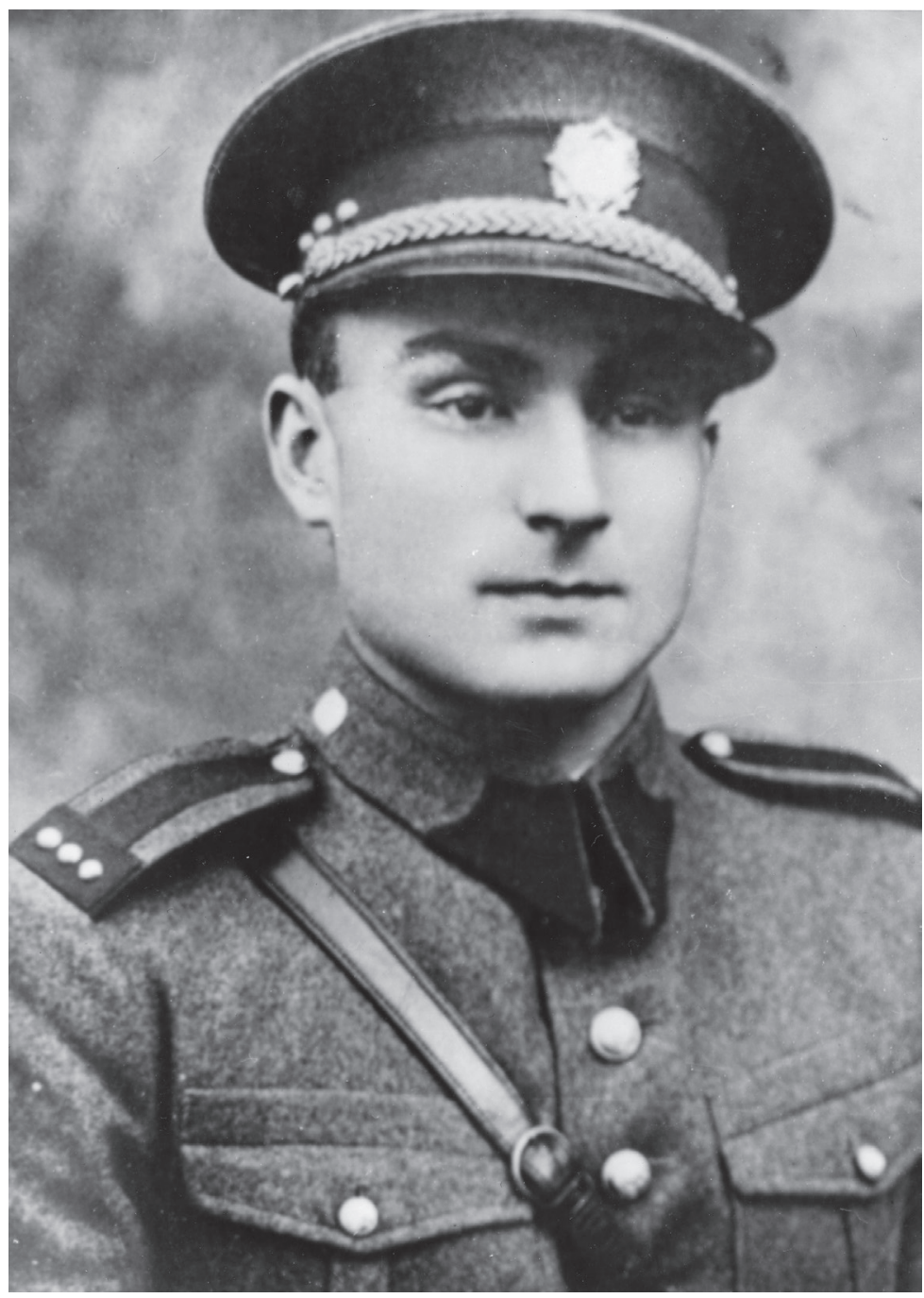

4 - La carrera de gendarme de Rudolf Bolfík duró menos de dos meses. Terminó rápida y repentinamente el 28 de noviembre de 1937, cuando abandonó el Cuartel de gendarmería de Brno, sin indicar la razón. (Fuente: colección personal de D. Majtenyi). 

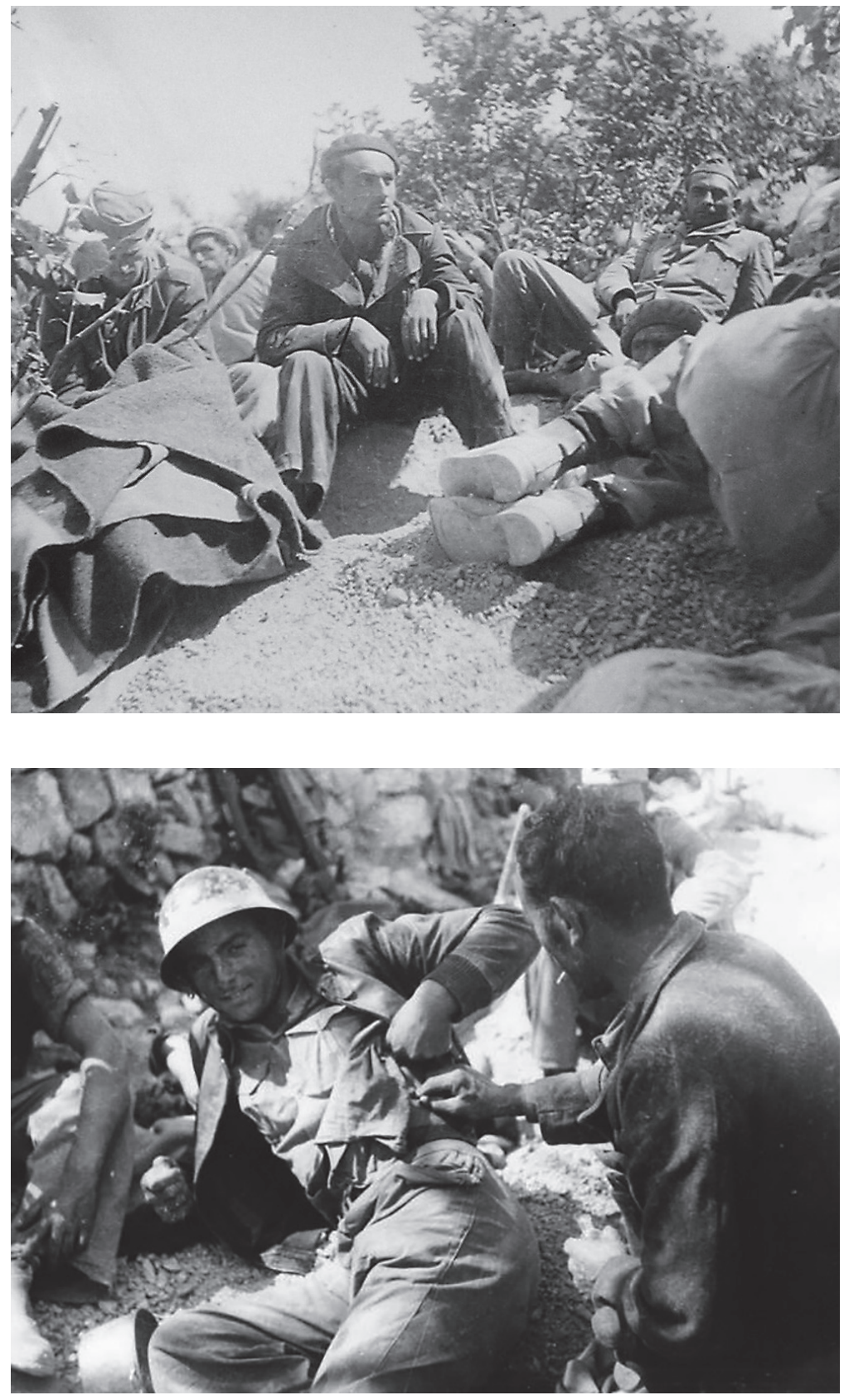

5a, 5b - Probablemente las únicas fotografías, conocidas hasta ahora, de Rudolf Bolfík como soldado de infantería en España, junto con sus compañeros de lucha del Batallón Divisionario. Las imágenes, tomadas en 1938 durante la batalla del Ebro en la que participó el batallón, evocan remotamente la atmósfera del "idilio" de trinchera. (Fuente: NA, Praha, via F. Helešic). 


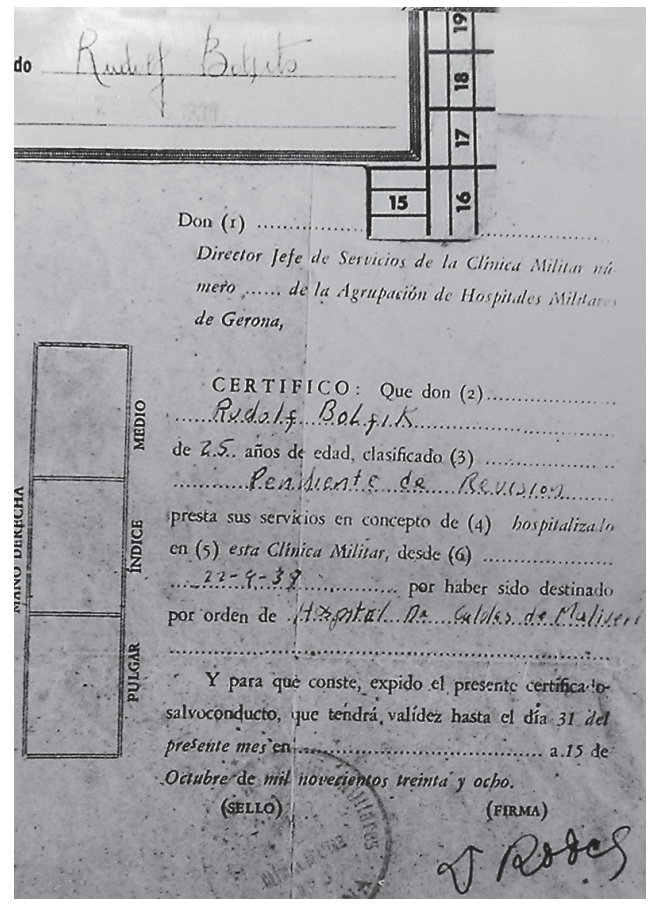

6 - Aunque Rudolf Bolfík luchó en España relativamente poco tiempo, fue herido tres veces. Del 9 al 26 de octubre de 1938 estuvo convaleciente en el hospital de ejército de Vichy. (Fuente: colección personal de J. Rajlich).

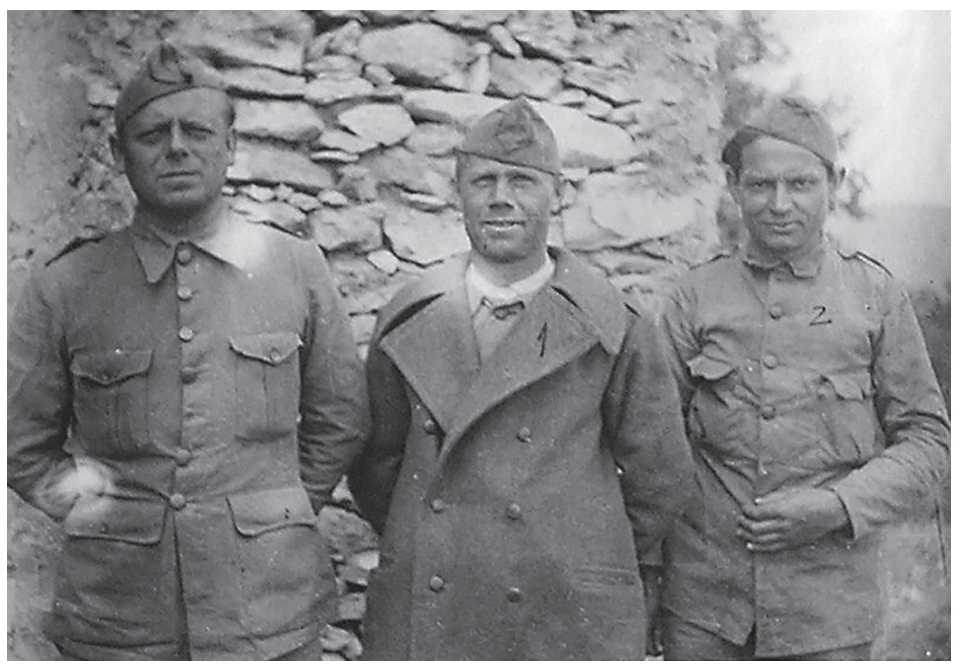

7 - Los compañeros de combate de Bolfík del Batallón Divisionario, Josef Cuc y Václav Kratochvíl (a la derecha) en Tortosa. (Fuente: NA, Praha). 

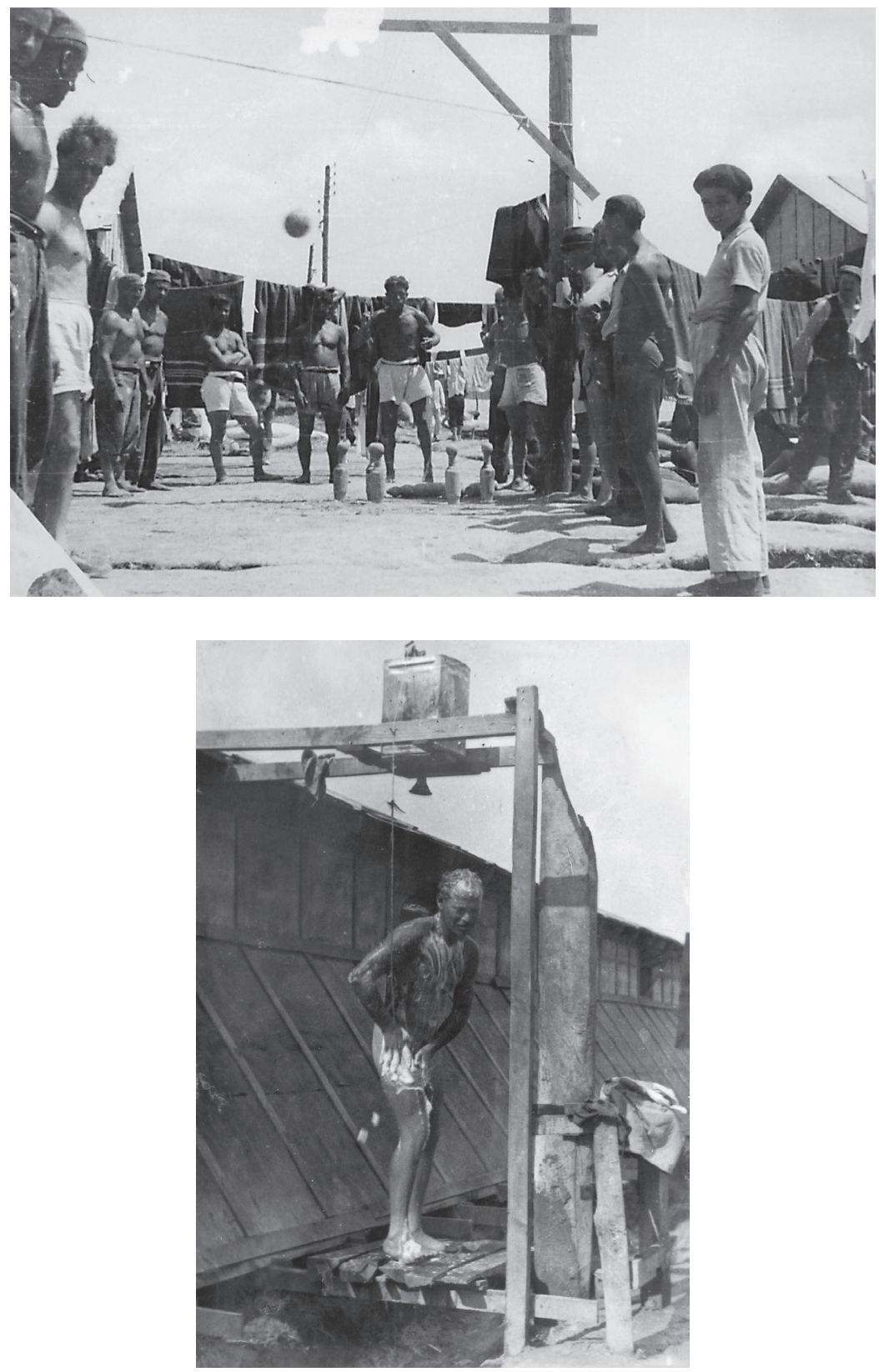

8a, 8b - Rudolf Bolfík fue obligado a pasar casi un año en los campamentos franceses para fugitivos, bajo unas condiciones de vida muy difíciles. Estas fotos, tomadas por nuestros interbrigadistas en uno de ellos, Camp Gurs, no tratan de polemizar de ninguna manera con este hecho. Su objetivo fue solamente hacer más civil y soportable la vida cotidiana, o más bien, una pervivencia en ellos. Aunque pudieran dar una impresión de cierta despreocupación, nada sería más alejado de la verdad. (Fuente: NA, Praha). 


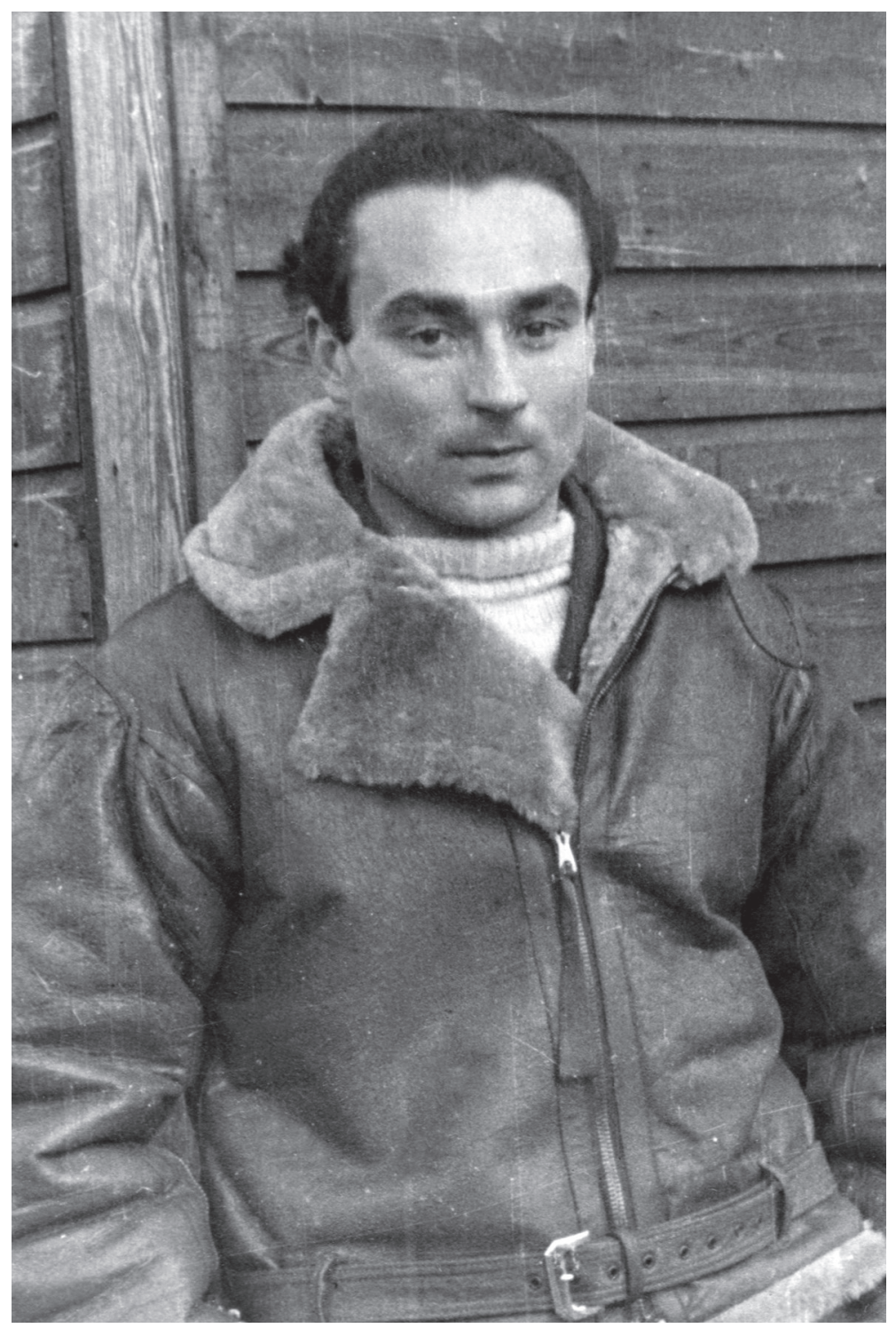

9 - Probablemente la última foto de Rudolf Bolfík, conocida hasta ahora. La cara y la mirada tensas de un hombre joven, conciliado con la vida, insinúa cuántas peripecias ya tiene detrás de sí y hace vislumbrar lo poco que tiene por delante. (Fuente: via F. Helešic) 


\section{BIBLIOGRAFÍA}

FRIEDL, Jiří, “'Španěláci’ z tábora Gurs. Ke vstupu čs. Interbrigadistů do naší armády ve Francii 19391940" ["Gallegos" del campamento Gurs. Acerca de la entrada de los interbrigadistas checoslovacos en nuestro ejército en Francia 1939-1940], Historie a vojenství 4, Praha: Vojenský historický ústav Praha - Armádní muzeum Žižkov, 2001, pp. 806-823.

HELEŠIC, František, "Z galerie statečných - Rudolf Bolfík" [Galería de los valientes - Rudolf Bolfík], Hlas revoluce 5, Praha: Svaz bojovníků za svobodu, 1984.

KEJÍK, František, "Dlaň člověka" [Palma del hombre], Obrana lidu, el 25 de diciembre de 1959.

LOUCKÝ, František, Mnozí nedoletěli [Muchos no han logrado volver], Praha: NV, 1989.

LUKEŠ, Petr, "Španělská válka interbrigadisty Adolfa Vodičky" [La guerra española del interbrigadista Adolf Vodička], en: 70. výročí ukončení španělské občanské války 2 [El 70 aniversario del fin de la Guerra Civil Española], (=Sborník Muzea dělnického hnutí [Almanaque del Museo del Movimiento Obrero]), Praha: Muzeum dělnického hnutí 2009, pp. 65-66.

PLACHÝ, Jiří, "Vzbouřenci z Cholmondeley 1. část" [Rebeldes de Cholmondeley, Ia parte], Historie a vojenství 3, Praha: Vojenský historický ústav Praha - Armádní muzeum Žižkov, 2016, pp. 19-38; "Vzbouřenci z Cholmondeley 2. část" [Rebeldes de Cholmondeley, II ${ }^{a}$ parte], Historie a vojenství 4 , Praha: Vojenský historický ústav Praha - Armádní muzeum Žižkov, 2016, pp. 20-57.

RAJLICH, Jiří, Na nebi hrdého Albionu. Válečný deník československých letců ve službách britského letectva 1940-1945 2. část (1941) [En el cielo del orgulloso Albión. Diario de guerra de aviadores checoslovacos a servicio de la Aviación británica 1940-1945, 2a parte (1941)], Cheb: Svět kř́́del, 2000.

RAJLICH, Jiří, Na nebi hrdého Albionu. Válečný deník československých letcư ve službách britského letectva 1940-1945. 7. část - Černá kronika čs. letectva v RAF 1940-1945 [En el cielo del orgulloso Albión. Diario de guerra de aviadores checoslovacos a servicio de la Aviación británica, 1940-1945, 7 parte - Crónica negra de la Aviación checoslovaca en las RAF 1940-1945], Cheb: Svět křídel, 2004.

RAJLICH, Jiří, Na nebi sladké Francie. Válečný deník československých letcư ve službách francouzského letectva 1939-1945 [En el cielo de la dulce Francia. Diario de guerra de aviadores checoslovacos a servicio de la Aviación francesa 1939-1945], Cheb: Svět kř́́del, 2008.

RAJLICH, Jiří - MAJTENYI, David, Jan Ferák a ti druzí - čs. interbrigadisté, letci a letouny v občanské válce ve Španělsku 1936-1939 [Jan Ferák y los demás: interbrigadistas checoslovacos, pilotos y aviones en la Guerra Civil de España 1936-1939], Cheb: Svět křídel, 2012.

RUTAR, Svatopluk, "Rudolf Bolfík, bojovník proti fašismu - vzpomínka ke 45. výročí úmrtî" [Rudolf Bolfík, combatiente contra el fascismo: Recuerdo en ocasión del 45 aniversario de su muerte], in: Sborník Jižní Morava 22/25, Brno: Muzejní a vlastivědná společnost, 1986, pp. 306-339.

RUTAR, Svatopluk, "Před 70 lety zahynul v boji Rudol Bolfík" [Hace 70 años pereció en la lucha Rudolf Bolfík], Malovaný kraj: národopisný a vlastivědný časopis Slovácka 2, Břeclav: Moraviapress, 2011.

RUTAR, Svatopluk, "Na kř́́dlech za svobodou” [En las alas por la libertad], Malovaný kraj XIX/4, Břeclav: Moraviapress, 1983.

VÁŇA, Josef - RAIL, Jan, Českoslovenští letci ve Francii 1939-1940 [Aviadores checoslovacos en Francia 1939-1940], Praha: AVIS, 2005.

VÁŇA, Josef - SIGMUND, John - PADIOR, Emil, Př́slušníci československého letectva v RAF [Miembros de la Aviación checoslovaca en las RAF], Praha: Ministerstvo obrany České republiky, 1999.

\section{Breve información sobre el autor}

PhDr. David Majtenyi (*1976) se graduó en Estudios Archivísticos y Ciencias Históricas Auxiliares en la Facultad de Filosofía de la Universidad Carolina (20132018). Actualmente trabaja como curador en el Museo del Archivo del Movimiento de los Trabajadores en el Archivo del Museo Nacional. Se dedica a la historia de la Fuerza Aérea de Checoslovaquia, la Guerra Civil Española, la resistencia comunista y la historia de los países eslavos del sur. 